\title{
Mosses in Brachypodio-Betuletea forests of West Siberia
}

\author{
Olga Pisarenko* \\ Central Siberian Botanical Garden SB RAS, 630090, Zolotodolinskaya Str., 101, Novosibirsk, Russia
}

\begin{abstract}
Brachypodio-Betuletea forests of West Siberia were evaluated for the mosses. The observed localities are in limits $51^{\circ} 48^{\prime}-56^{\circ} 48^{\prime} \mathrm{N}$ and $60^{\circ} 16^{\prime}-88^{\circ} 20^{\prime}$ E. 93 moss species are registered their, but only 36 are common. Most of the species are associated with Betula-trunks. The list of species and their occurrence by main types of the forests are given. The diversity and abundance of mosses correlate with the community humidity, decreasing with xerophytization. It is shown that on the studied territory moss species composition and constancy well indicate the latitudinal replacement of classes of forest vegetation.
\end{abstract}

The southern periphery of the forest zone in West Siberia, toward south of $57-56^{\circ} \mathrm{N}$, is composed of birch and aspen-birch grass forests. The forests are regarded to be indigenous here. They are considered as vicariant to broad-leaved and coniferous-broad-leaved forests of the ocean regions $[1,2]$. In the Braun-Blanquet approach, they are allocated in the class Brachypodio pinnati-Betuletea pendulae Ermakov et al. 1991. Forests with the dominance or participation of pine on the territory are azonal and restricted by sandy or gravelly substrates and, accordingly, take place mainly on the ancient high terraces of large rivers and in ancient runoff ravines. The pine forests are also included into class BrachypodioBetuletea.

Vast gradient of heat and moisture values from North to South and regional variation in flora cause significant difference in the composition of the grass and shrub layers in the discussed forests. As result a lot of associations of floristic classification were described. Meanwhile, today for the territory there is no prodromus of vegetation unites.

Bryophyte investigation of the forests was carried out in the 2009-2016 years, together with geobotanical ones; 252 plots were examined on the territory of Novosibirsk, Kemerovo, Omsk, Tyumen provinces and Altai Territory in limits $51^{\circ} 48^{\prime}-56^{\circ} 48^{\prime} \mathrm{N}$ and $60^{\circ} 16^{\prime}-88^{\circ} 20^{\prime} \mathrm{E}$.

In sum in the investigated spots 93 moss species were recorded; 67 of them were found more then once (table), but only 36 are more or less common.

Meticulous bryophyte investigations of Bashkiria forests were shown the absence diagnostic mosses for particular forest associations, the specificity of bryopvhyte composition of individual associations is extremely low [3]. Therefore, to describe the

\footnotetext{
*Corresponding author: o pisarenko@,mail.ru
} 
distribution of mosses, I integrated ecologically and geographically similar associaton and arranged the examined forest communities into 6 groups according their habitat specifity, species composition and distribution. For the listed below groups I indicated their syntaxonomic position; abbreviation used in the table is given in brackets.

- moist tall-herbaceous birch and birch-aspen forests; common in sub-taiga; order Carici macrourae-Pinetalia sylvestris, alliance Lathyro gmelinii-Pinion sylvestris (b1).

- mesophytic birch and aspen-birch herbaceous forests; common in sub-taiga and foreststeppe of the south-eastern part of West Siberia and foothills of Altai-Sayan region; order Calamagrostio epigeii-Betuletalia pendulae, alliance Calamagrostio epigeiiBetulion pendulae (b2).

- mesophytic and moderately dry birch herbaceous forests of Baraba forest-steppe zone; order Carici macrourae-Pinetalia sylvestris, alliance Vicio unijugae-Pinion sylvestris (b3).

- moderately dry birch herbaceous forests of forest-steppe zone West of the Ob-River; order Calamagrostio epigeii-Betuletalia pendulae, alliance Peucedano morisoniiBetulion pendulae (b4).

- mesophytic pine and birch-pine shrub-herbaceous forests of Ob-River terraces and ancient runoff ravines; order Calamagrostio epigeii-Betuletalia pendulae, alliance Peucedano morisonii-Betulion pendulae (p1).

- mesophytic pine and birch-pine shrub-herbaceous forests of Salair ridge; order Carici macrourae-Pinetalia sylvestris, alliance Vicio unijugae-Pinion sylvestris (p2).

All investigated types of birch and aspen forests are similar in set of constant moss species (table, upper part). The differences mainly related to rare and random species (table, lower part). The diversity and abundance of mosses correlate with the community humidity and decrease with xerophytization. So in the most moist Lathyro gmelinii-Pinion forests 64 moss species were recorded; in Vicio unijugae-Pinion forests - 61 species, in Calamagrostio epigeii-Betulion forests - 42; in Peucedano morisonii-Betulion - 16. In all types of herbaceous small-leaved forests the main ecotope for mosses are trunks of the dominant tree, Betula pendula or B. pubescens. Soil surface in the forests under close herb layer is covered by hay and forest litter; a dead-fall usually is dry and not populated by mosses or completely absent due to periodic ground fires. Moss abundance on tree trunks depends on many factors: the thickness and inclination of the trunk, total humidity, snow depth in winter, position of the community/tree in the relief. In old-growth birch forests of sub-taiga zone on trunks about $40 \mathrm{~cm}$ diameter mosses grow up to $60-80 \mathrm{~cm}$ above ground. In dry insular birch groves of forest-steppe zone the range is reduced to $15-20 \mathrm{~cm}$.

A set of mosses living in pine forests is almost the same as in small-leaved ones (table). Only a few species grow on soil: Pleurozium schreberi is the most common; Ptilium cristacastrensis and Dicranum polysetum take place; other 'taiga species' - Hylocomium splendens Rhytidiadelphus triquetrus and Polytrichum commune - are relatively rare. In birch and aspen forests all moss species sometimes occur on tree trunks. Moss diversity in pine forests is caused by species growing on tree trunks. Most species were found on birches which are usually solitary present in the pine forests. In the result moss species lists of small-leaved and pine forests of Brachipodio-Betuletea on the territory are very similar (table).

In forest zone of West Siberia Betula pendula and B. pubescens are widespread from its southern to northern limits. In subtaiga and forest-steppe zones the presence of Betula-trees provides the similarity of moss lists in different types of forest communities. But further south and north bryophyte component of forest communities undergoes appreciable changes. Geographic ranges of many epiphytic species extends further north to Middle and North taiga zones and even to Forest-Tundra. But afore, in the Southern taiga zone, most of them (Platygyrium repens, Callicladium haldanianum, Stereodon pallescens, Dicranum 
montanum, etc.) disappear or sharply reduce the constancy and abundance in zonal communities and occur mainly in valley forests [4]. Even more drastic changes in bryophyte population of forest communities occur in the southern direction. Toward south limit of forest-steppe subzone, small-leaved forests lose their zonal positions; they occur on spots with higher humidity. Species composition of these forests differs from this one of the communities of Brachypodio-Betuletea [2]. These forests are extremely poor in mosses. Only 13 species were recorded there. They have contrast ecological features. Five of them are never noted in the discussed Brachypodio-Betuletea communities (Bryum creberrimum, Leptodictyum riparium, Pterygoneurum kozlovii, Tortula muralis, Warnstorfia fluitans).

So, in south of West Siberia moss species composition and constancy well indicate the latitudinal replacement of classes of forest vegetation.

Table. Occurrence of moss species in investigated types of Brachypodio-Betuletea forests.

\begin{tabular}{|c|c|c|c|c|c|c|}
\hline \multirow{4}{*}{$\begin{array}{r}\text { Number of releves } \\
\text { Number of moss species }\end{array}$} & \multicolumn{6}{|c|}{ Community type } \\
\hline & p1 & p2 & b1 & b2 & b3 & b4 \\
\hline & 55 & 20 & 67 & 21 & 102 & 6 \\
\hline & 67 & 41 & 64 & 42 & 61 & 16 \\
\hline Pylaisia polyantha & III & III & $\mathrm{V}$ & $\mathrm{V}$ & $\mathrm{V}$ & $\mathrm{V}$ \\
\hline Amblystegium serpens & IV & + & IV & $\mathrm{V}$ & $\mathrm{V}$ & $\mathrm{V}$ \\
\hline Ceratodon purpureus & II & I & I & II & II & III \\
\hline Stereodon pallescens & III & III & III & III & IV & $\mathrm{V}$ \\
\hline Orthotrichum speciosum & II & + & III & II & III & III \\
\hline Sanionia uncinata & IV & III & IV & III & IV & IV \\
\hline Brachythecium salebrosum & IV & IV & IV & IV & III & I \\
\hline Platygyrium repens & II & + & III & III & III & I \\
\hline Brachythecium capillaceum & II & & III & III & III & II \\
\hline Sciuro-hypnum reflexum & III & I & III & + & III & II \\
\hline Callicladium haldanianum & IV & II & III & III & III & II \\
\hline Dicranum montanum & II & III & III & III & II & II \\
\hline Pohlia nutans & III & II & II & III & II & IV \\
\hline Orthotrichum obtusifolium & $\mathrm{I}$ & + & III & III & II & II \\
\hline Plagiothecium denticulatum & I & + & I & + & II & II \\
\hline Pylaisia selwynii & . & & II & I & I & I \\
\hline Plagiomnium cuspidatum & IV & II & IV & III & IV & . \\
\hline Pleurozium schreberi & III & V & II & III & II & . \\
\hline Haplocladium microphyllum & II & & II & III & II & . \\
\hline Dicranum fuscescens & + & IV & II & II & II & . \\
\hline Sciuro-hypnum curtum & III & + & II & + & I & . \\
\hline Dicranum polysetum & II & IV & II & II & + & . \\
\hline Ptilium crista-castrensis & II & $\mathrm{V}$ & II & I & + & . \\
\hline Rhytidiadelphus triquetrus & I & + & II & + & + & . \\
\hline Campylidium sommerfeltii & I & + & I & + & + & . \\
\hline Plagiomnium ellipticum & + & & + & + & + & . \\
\hline Oncophorus wahlenbergii & + & + & I & I & + & . \\
\hline Dicranum flagellare & + & + & + & I & + & . \\
\hline Climacium dendroides & + & II & + & + & + & . \\
\hline Polytrichum juniperinum & I & I & + & + & + & . \\
\hline Calliergonella lindbergii & . & . & + & + & + & . \\
\hline Plagiothecium laetum & + & + & + & + & + & . \\
\hline Leskea polycarpa & II & . & I & . & II & . \\
\hline Plagiomnium medium & + & II & + & + & . & . \\
\hline Rhodobryum roseum & + & II & + & . & + & . \\
\hline
\end{tabular}




\begin{tabular}{|l|c|c|c|c|c|c|} 
Funaria hygrometrica & I & $\cdot$ & $\cdot$ & + & + & $\cdot$ \\
Leptobryum pyriforme & I & I & $\cdot$ & $\cdot$ & + & $\cdot$ \\
Dicranum scoparium & + & $\cdot$ & $\cdot$ & $\mathrm{I}$ & + & $\cdot$ \\
Abietinella abietina & + & $\cdot$ & + & $\cdot$ & + & $\cdot$ \\
Atrichum flavisetum & $\mathrm{I}$ & + & $\cdot$ & $\cdot$ & + & $\cdot$ \\
Aulacomnium palustre & + & $\cdot$ & + & $\cdot$ & $\cdot$ & $\cdot$ \\
Barbula unguiculata & + & $\cdot$ & $\cdot$ & + & + & $\cdot$ \\
Brachythecium baicalense & + & + & $\cdot$ & $\cdot$ & $\cdot$ & $\cdot$ \\
Brachythecium mildeanum & + & $\cdot$ & + & + & $\cdot$ & $\cdot$ \\
Brachythecium rutabulum & + & $\cdot$ & + & $\cdot$ & $\cdot$ & $\cdot$ \\
Bryoerythrophyllum recurvirostrum & + & + & $\cdot$ & $\cdot$ & + & $\cdot$ \\
Bryum caespiticium & + & + & $\cdot$ & $\cdot$ & + & $\cdot$ \\
Campyliadelphus chrysophyllus & + & $\cdot$ & $\cdot$ & $\cdot$ & + & $\cdot$ \\
Dicranum bonjeanii & $\cdot$ & $\cdot$ & + & $\cdot$ & + & $\cdot$ \\
Eurhynchiastrum pulchellum & + & $\cdot$ & + & $\cdot$ & + & $\cdot$ \\
Fissidens bryoides & + & $\cdot$ & + & $\cdot$ & $\cdot$ & $\cdot$ \\
Homalia trichomanoides & + & $\cdot$ & + & $\cdot$ & + & $\cdot$ \\
Hygroamblystegium varium & + & $\cdot$ & $\cdot$ & + & + & $\cdot$ \\
Hylocomium splendens & + & + & + & $\cdot$ & $\cdot$ & $\cdot$ \\
Mnium stellare & + & $\cdot$ & + & $\cdot$ & $\cdot$ & $\cdot$ \\
Oxyrrhynchium hians & + & $\cdot$ & + & $\cdot$ & $\cdot$ & $\cdot$ \\
Pohlia cruda & + & $\cdot$ & + & $\cdot$ & + & $\cdot$ \\
Polytrichum commune & + & + \\
Polytrichum piliferum & + & + & $\cdot$ & $\cdot$ & + & $\cdot$ \\
Pseudoleskeella nervosa & + & $\cdot$ \\
Rhytidiadelphus subpinnatus & + & $\cdot$ & + & $\cdot$ & + & $\cdot$ \\
Sciuro-hypnum starkei & + & $\cdot$ & $\cdot$ & + & $\cdot$ \\
Serpoleskea subtilis & + & + & $\cdot$ \\
Tetraphis pellucida & + & $\cdot$ & + & $\cdot$ & + & $\cdot$ \\
Thuidium recognitum & + & $\cdot$ & $\cdot$ \\
Timmia megapolitana & + & + & + & + & $\cdot$ & $\cdot$ \\
Weissia brachycarpa & + & + & + & $\cdot$ & $\cdot$ \\
\hline
\end{tabular}

Note. Species with solitary records are not included. Nomenclature follows to [5]. Community types are explained in the text. Occurrence classes (ranges of the percentage of releves in which the species is registered): $\mathrm{V}-81-100 \%$; IV $-61-80 \%$, III $-41-60 \%$; II $-21-40 \%$, I $-11-20 \%$, + less than $10 \%$.

The work response to state assignment AAAA-A17-117012610052-2 and biocollection development № USU 440537, partly supported by RFFI №18-04-00822.

\section{References}

1. N.N. Lavrenko, The vegetation of the West Siberian plain (Novosibirsk, 1985)

2. N.N. Lashchinskiy, The vegetation of East Europe and North Asia, 87 (2014)

3. E.Z. Baisheva, V.B. Martynenko, P.S. Shirokikh, Bryophyta of forest ecosystems of Bashkortostan Republic (Ufa, Gilem, Bashk. Enzikl, 2015)

4. O.Yu. Pisarenko, Plant world of Asian Russia, 2(14), 24-28 (2014)

5. M.S. Ignatov, O.M. Afonina, E.A. Ignatova et al., Arctoa, 15 (2006) 